\title{
GAMBARAN STATUS DEMENSIA DAN DEPRESI PADA LANSIA DI WILAYAH KERJA PUSKESMAS GUNTUR KELURAHAN SUKAMENTRI GARUT
}

\author{
Yupira Dera Sopyanti ${ }^{1}$, Citra Windani Mambang Sari ${ }^{2}$, NinaSumarni $^{3}$ \\ Universitas Padjadjaran \\ yupiradera96@gmail.com
}

\begin{abstract}
ABSTRAK
Jumlah penduduk lanjut usia di Indonesia tahun 2014 mencapai 18,8 juta jiwa dan pada pada tahun 2025 akan mencapai 36 juta jiwa. Seiring meningkatnya usia, perubahan fungsi kognitif pada lansia juga mengalami peningkatan. Gangguan fungsi kognitif pada lansia dapat menyebabkan perubahan kepribadian, emosi, dan mengganggu aktivitas sehari - hari, apabila berlangsung secara progresif maka dapat terjadi demensia dan perubahan psikososial seperti depresi. Dengan diketahuinya status demensia dan depresi pada lansia di masyarakat dapat digunakan sebagai data dasar dalam mengembangkan program yang berhubungan dengan kesehatan lansia di masyarakat. Penelititian ini bertujuan untuk memperoleh gambaran status demensia dan depresi pada lansia di masyarakat. Metode yang digunakan pada penelitian ini adalah deskriptif dengan pendekatan kuatitatif. Data dikumpulkan dengan kuisioner Modified Mini Mental State Test (3MS) dan Geriatric Scale Depression (GDS) pada responden 112 lansia yang diambil dengan menggunakan teknik random sampling di wilayah kerja Puskesmas Guntur Kelurahan Sukamentri Garut. Analisis menggunakan statistik deskritif dengan distribusi frekuensi. Hasil penelitian ini didapatkan dengan kategori demensia ringan, yaitu sebanyak 55 responden $(49,1 \%)$, dengan kategori demensia sedang sebanyak 45 responden $(37,5 \%)$, sedangkan kategori demensia berat sedang sebanyak 15 responden $(13,4 \%)$. Hasil penelitian status depresi dalam kategori normal sebanyak 32 responden $(28,6 \%)$, kategori depresi ringan sebanyak 45 responden $(40.2 \%)$, kategori depresi sedang sebanyak 23 responden (20,5\%) dan kategori depresi berat sebanyak 12 responden (10,7\%). Petugas kesehatan diharapkan dapat menjadikan hasil penelitian ini sebagai dasar dalam mengembangkan program kegiatan kesehatan lansia seperti posbindu pada lansia dengan memberikan penyuluhan berupa informasi dan edukasi terkait demensia dan depresi, membina lansia dalam menjaga fungsi kognitif dan psikososialnya (olahraga, membaca buku, kegiatan keterampilan).
\end{abstract}

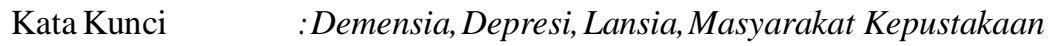

\begin{abstract}
The number of elderly population in 2014 reached 18.8 million people and will become 36 million in 2015. As the age increases, changes in cognitive function will also improve. Impaired cognitive function can cause personality and emotional changes which interfere daily activities. If this cognitive function disorder occurs progressively, it will lead to dementia and psychological changes such as depression. Knowing the dementia and depression status for older people in society is very useful as the basic data in developing the program relating to the elderly health in society. This study is intended to find out the description of dementia and depression status for elderly people in society. The research method used was descriptive quantitative approach. The data was collected through Modified Mini Mental State Test (3MS) and Geriatric Scale Depression (GDS) questionnaire. The random sampling technique was used to select the sample. There were 122 elderly people in Community Health Center of Guntur Sukamentri Sub-district Garut as samples. The data analysis used was descriptive statistics with distribution. Based on the result of the study, 55 respondents (49.1\%) belonged to mild dementia, moderate dementia for 45 respondents (37.5\%), and severe dementia for 15 respondents (13.4\%). In terms of depression, 32 respondents (28.6\%) included to the normal, mild depression for 45 respondents (40.2\%), moderate depression for 23 respondents (20.5\%), and severe depression for 12 respondents (10.7\%). The health workers are expected to make this result of the study as reference in developing health program for elderly people such as integrated counseling post program by informing and educating about dementia and depression, and also by guiding the elderly people to maintain cognitive and psychosocial functions (exercising, reading books, improving skill activities).
\end{abstract}

Keywords : Dementia, Depression, Elderly, People, Society

26 


\section{PENDAHULUAN}

Data dari World Health Organization (WHO) dan Alzheimer's Disease International Organization memaparkan jumlah total orang dengan demensia di seluruh dunia pada tahun 2015 mencapai 47,5 juta dan berjumlah 22 juta jiwa yang kebanyakan terdapat di Asia. Di negara maju seperti Amerika Serikat saat ini didapatkan lebih dari 4 juta jiwa usia lanjut penderita Demensia. Jumlah ini akan terus meningkat hampir 4 kali pada tahun 2050 . Total kasus demensia baru setiap tahun di seluruh dunia berkisar 7,7 juta, artinya setiap 4 detik terdapat 1 kasus demensia diperkirakan akan terus naik jadi 75,6 juta pada tahun 2030 dan 135,5 juta pada tahun 2050 (WHO, 2015). Peningkatan pesentase lansia akan terus meningkat setiap tahunnya, dan angka beban tanggungan juga akan terus meningkat seiring meningkatnya jumlah populasi lansia (Kemenkes RI, 2014).

Penyakit kronis yang banyak ditemukan pada lansia di komunitas akibat faktor penuaan semua fungsi dan sistem tubuh adalah seperti diabetes mellitus, artritis, gangguan pendengaran, demensia, masalah jantung dan hipertensi (Anderson, 2011 dan Anderson, 2007). Hal inilah sangat perlu diperhatikan oleh tenaga kesehatan terutama oleh perawat komunitas dalam mengatasi masalah risiko depresi pada lansia.

Demensia adalah sindrom terjadinya penurunan memori, berpikir, perilaku, dan kemampuan melakukan kegiatan seharihari pada seseorang. Dari beberapa pengertian di atas dapat disimpulkan bahwa demensia merupakan kumpulan gejala yang berlangsung secara progresif yang ditandai dengan perubahan perilaku, penurunan memori, orientasi, kesulitan dalam berkomunikasi dan mengambil keputusan sehingga mengakibatkan kegiatan sehari- harinya terganggu (WHO, 2016). Total penderita penyakit demensia di Indonesia pada tahun 2013 mencapai satu juta orang (Kemenkes, 2016). Penyakit atau gangguan umum pada lansia salah satunya yaitu demensia, dimana gejalanya adalah kemunduran kognitif yang sedemikian parahnya, sehingga dapat mengganggu aktivitas dan kegiatan sosial lannya. Kejadian tersebut membuat penderita tidak mampu melaksanakan kegiatan seperti sedia kala karena adanya penurunan memori dan daya ingat yang semakin lemah (Nugroho, 2008).

Demensia akan dimulai secara perlahan dan makin lama makin parah, sehingga kondisi ini pada awalnya tidak di sadari. Terjadi penurunan dalam ingatan, kemampuan untuk mengingat waktu, mengenali orang, tempat dan benda. Gejala awal biasanya adalah kemunduran fungsi kognitif ringan, kemunduran dalam mempelajari hal-hal baru, ingatan terhadap peristiwa jangka pendek menurun, dan kesulitan menemukan kata-kata yang tepat (Pieter, Janiwarti, \& Saragih, 2011). Penyebab demensia yaitu kematian sel sel saraf atau hilangnya komunikasi antar sel sel yang ada di otak. Otak manusia layaknya mesin yang sangat kompleks dan rumit sehingga banyak faktor kompleks yang mengganggu komunikasi antar sel sel saraf satu dengan sel lainnya. Hasil penelitian telah ditemukan bahwa faktor yang mempengaruhi demensia yaitu karena penyalahgunaan zat adiktif yang banyak (Braindisorder, 2010).

Demensia atau penyakit pikun dapat menyebabkan perubahan cara berpikir dan berinteraksi dengan orang lain. Seringkali, memori jangka pendek, pikiran, kemampuan berkomunikasi dan kemampuan motorik terpengaruh. Demensia pada lansia akan memberi dampak pada kemunduran kapasitas intelektual, gangguan emosi, gangguan kognitif dan gangguan psikomotor, dan akan mempengaruhi pekerjaan, aktivitas sosial serta hubungan dengan orang lain (Braindisorder, 2012) 
Demensia dapat berpengaruh pada fisik, psikososial, spiritual, dan kognitif. Salah satunya mengganggunya pada fisik yaitu dapat menyebabkan penyakit iskemik dan terjadi disfungsi otak, seperti hepar yang membesar dan ensefalopati hepatik, atau menunjukan adanya penyakit sistemik yang berhubungan dengan proses pada sistem saraf pusat. Dengan adanya penyakit demensia penderita dapat megalami resiko jatuh karena penurunan fungsi syarat dan otot yang melemah (Pishvaei, Moghanloo, \& Moghanloo, 2015). Perjalanan penyakit demensia dapat mempengaruhi psikologisnya, orang yang mengalami demensia cenderung akan mengalami stress dan gejala ansietas karena hal tersebut lansia akan merasa tidak bisa melakukan aktivitas apapun dan merasa selalu dianggap sebagai orang yang menyusahkan untuk orang lain khususnya keluarga (Azizah, 2011).

Depresi menurut World Health Organization (WHO, 2012). Merupakan suatu gangguan mental umum yang ditandai dengan mood tertekan, kehilangan kesenangan atau minat, perasaan bersalah atau harga diri rendah, gangguan makan atau tidur, kurang energi, dan konsentrasi yang rendah. Masalah ini dapat akut atau kronik dan menyebabkan gangguan kemampuan individu untuk beraktivitas sehari-hari. Pada kasus parah, depresi dapat menyebabkan bunuh diri. Sekitar $80 \%$ lansia depresi yang menjalani pengobatan dapat sembuh sempurna dan menikmati kehidupan mereka, akan tetapi 90\% mereka yang depresi mengabaikan dan menolak pengobatan gangguan mental tersebut.

Menurut WHO prevalensi depresi pada lansia di dunia berkisar $8-15 \%$ dan hasil meta analisis dari laporan negara-negara di dunia mendapatkan prevalensi rata-rata depresi pada lansia adalah 13,5\% (Kompas, 2012). Prevalensi depresi pada lansia di Vietnam dan Jepang yang diukur pada penelitian yang sama menunjukan angka lebih rendah dibandingkan Indonesia, di Indonesia menurut penelitian yang telah dilakukan dengan pengukuran menggunakan Geriatric Depression Scale Short Form (GDS-SF) sebanyak 33,8\% (Wada T dkk, 2005 dalam Kartika Sari, 2012). Menurut Asniati (2013) depresi memiliki ciri yang khas karena terjadi bersamaan dengan adanya penurunan fungsi-fungsi tubuh akibat dari penuaan. Gangguan alamiah tersebut akan mengakibatkan perubahan perilaku pada dirinya dan dapat menganggu fungsi kehidupannya mulai dari kognitif, motivasi, emosi dan perasaan, tingkah laku sampai pada penurunan kondisi fisik.

Depresi pada lansia adalah proses patologis, bukan merupakan proses normal dalam kehidupan. Umumnya orang-orang akan menanggulanginya dengan mencari dan memenuhi rasa kebahagiaan. Bagaimanapun lansia cenderung menyangkal bahwa dirinya mengalami depresi. Gejala umumnya banyak diantara mereka muncul dengan menunjukkan sikap rendah diri dan biasanya sulit untuk di diagnosis (Iskandar, 2012). Menurut Depkes RI (2007), gejala depresi berbedabeda dari satu orang ke orang lainnya hal tersebut dipengaruhi oleh beratnya gejala. Depresi mempengaruhi fisik, perasaan, pikiran dan kebiasaan sehari-hari (perilaku). Faktor psikososial yang mempengaruhi depresi lansia, telah ditunjukkan dalam sebuah penelitian oleh Widiatmoko (2010), bahwa dukungan sosial memiliki korelasi negatif yang tinggi dan bermakna terhadap timbulnya gejalagejala depresi lanjut usia. Depresi terjadi lebih banyak pada umur yang lebih tua dan dukungan keluarga yang rendah. Faktorfaktor psikososial usia lanjut merupakan permasalahan yang sangat rawan membebani kehidupannya yang pada gilirannya dapat mempengaruhi gangguan fisik, sosial, dan mentalnya.Stresor yang dihadapi lansia antara lain: modernisasi (adanya pola keluarga besar ke pola keluarga kecil yang terdiri dari ayah, ibu, 
dan anak dapat menempatkan lansia di luar sistem keluarga kecil tersebut, sehingga lansia merasa diabaikan), kesepian (adanya ibu rumah tangga yang bekerja, meninggalkan beban pekerjaan pada lansia), pekerjaan (pensiun seringkali disamakan dengan kehilangan kegiatan, penghasilan, kedudukan, berkurangnya harga diri, dan tidak mempunyai peran).

Pada umumnya lansia mengalami depresi ditandai oleh mood depresi menetap yang tidak naik, gangguan nyata fungsi atau aktivitas sehari-hari, dan dapat berpikiran atau melakukan percobaan bunuh diri. Pada lansia gejala depresi lebih banyak terjadi pada orang dengan penyakit kronik, gangguan kognitif, dan disabilitas. Kesulitan konsentrasi dan fungsi eksekutif lansia depresi akan membaik setelah depresi teratasi. Gangguan depresi lansia dapat menyerupai gangguan kognitif seperti demensia. Beberapa penelitian memperlihatkan banyaknya lansia yang mengalami demensia, diantaranya adalah hasil penelitian yang dikemukakan Sengkey (2017) bahwa kejadian demensia lanjut usia di BPLU Senja Cerah provinsi Sulawesi Utara dengan presentase terbanyak gangguan kejadian demensia sedang. Penelitian yang dilakukan Ukus (2015) menyebutkan sebelum di berikan logoterapi mengenai kebermaknaan hidup terdapat 11 responden yang mengalami kebermaknaan hidup kurang dan 4 responden yang mengalami kebermaknaan hidup cukup. Sedangkan sesudah di berikan logoterapi mengenai kebermakaan hidup terdapat 12 responden yang mengalami kebermaknaan hidup cukup dan 3 responden yang mengalami kebermaknaan hidup kurang.

Sedangkan hasil penelitian Hananta dkk (2011) mendapatkan hasil dari 95 responden lansia yang tinggal di 3 panti werdha wilayah Tanggerang, sebanyak 54 orang mengalami demensia dan 41 orang tidak mengalami demensia. Kuesioner yang digunakan pada penelitian ini adalah mini mental status examination (MMSE), dikatakan demensia jika nilai MMSE < 24 . Begitu juga hasil penelitian Untari (2014), mengukur tingkat demensia pada 60 responden lansia di panti Werdha Darma Bakti Surakarta, menunjukan hasil lansia dengan kategori demensia berat sebanyak 28 orang $(46,7 \%)$. Selain itu peneliti lain dengan quesioner mental status examination (MMSE) juga dilakukan oleh Maryam dkk (2015) pada 4 panti sosial Tresna Werdha yang berada di wilayah Jakarta dengan metode non eksperimen mendapatkan hasil hampir $30 \%$ lansia mengalami demensia.

Hasil penelitian yang di kemukakan oleh Ningsih et.al (2017), gambaran status demensia pada lansia di wilayah kerja puskesmas Ibrahin Adjie Kota Bandung, dengan metode penelitian deskriptif dengan pendekatan kuantitatif. Data di kumpulkan dengan menggunakan kuisioner Early Dementia Questionnaire (EDQ), yang dilakukan pada 98 responden bahwa lansia yang termasuk kategori early dementia dengan persentasi $38,8 \%$ dan lansia yang termasuk kategori normal dengan persentasi $61,2 \%$. Dilihat dari 6 domain status demensia, daya ingat, konsentrasi, gejala, fisik, emosi, gangguan tidur dan gejala lain, yang dilakukan oleh peneliti didapatkan hasil domain konsentrasi yang cenderung tinggi sebanyak 70 responden $(71,4 \%)$ dan pada domain gejala lansia lain rendah sebanyak 83 responden $(84,7 \%)$. Berdasarkan karakteristik responden early dementia paling banyak pada usia 60- 74 tahun sebanyak 26 responden $(39,4 \%)$, jenis kelamin perempuan sebanyak 29 responden $(40,9 \%)$ dan pada pendidikan sekolah dasar sebanyak 20 responden $(38,5 \%)$.

Hasil penelitian yang dilakukan oleh Marta (2012), tidak adanya hubungan yang signifikan antara dukungan keluarga dengan depresi pada lansia dengan nilai $\mathrm{p}=0,661$. Hal ini disebabkan karena para lansia tidak ingin menyusahkan keluarga dan ingin mandiri selama hidup di panti 
tersebut. Berdasarkanhasil wawancara dan pengamatan pada saat penelitian, sebagian besar lansia yang berada di panti sosial sudah jarang dan bahkan ada yang tidak pernah dikunjungi oleh keluarga. Hal ini dapat mempersulit komunikasi antara keluarga dengan lansia, sehingga lansia akan merasa kesepian karena kurangnya perhatian dan dukungan yang diberikan oleh keluarga. Dampak dari kurangnya perhatian dan dukungan dari keluarga salah satunya adalah dapat mencetuskan kejadian depresi.

Berdasarkan hasil penelitian yang dialakukan oleh Prabhaswari (2015) didapatkan bahwa responden yang mengalami depresi sebanyak 22 orang $(24,4 \%)$, sedangkan yang tidak mengalami depresi lebih dari tiga kali lipatnya yakni sebanyak 68 orang $(75,6 \%)$. Proporsi kejadian depresi paling tinggi ditemukan pada kelompok usia 70 tahun ke atas. Ditinjau dari jenis kelamin, angka depresi lebih tinggi pada responden perempuan dibandingkan laki-laki. Proporsi depresi juga ditemukan lebih tinggi pada responden yang berpendidikan rendah $(27,6 \%)$, sedangkan di antara responden yang berpendidikan tinggi hanya satu orang $(11,1 \%)$ yang mengalami depresi. Responden yang berstatus tidak menikah memiliki proporsi depresi lebih tinggi. Begitu pula dengan responden yang tidak bekerja, memiliki angka depresi yang lebih tinggi dibandingkan dengan mereka yang masih bekerja.

Penelitian yang dilakukan Indriana et.al pada tahun 2010 pada 32 lansia Panti werdha Pucang Gading Semarang menunjukkan $81,25 \%$ lansia mengalami stres berat dengan skor di atas 150 dan $18,75 \%$ menunjukkan keluhan sedang. Salah satu faktor yang menyebabkan stres pada lansia di panti adalah ketiadaan kebersamaan dengan anggota keluarga sehingga mereka merasa dicampakan atau tersisih. Tetapi penelitian di daerah Jawa Tengah yang dilakukan oleh Syahnur pada tahun 2006 tentang perbandingan stres antara lansia yang tinggal terpisah dari keluarga dengan lansia yang tinggal bersama keluarga menyatakan bahwa stres pada lansia tidak dipengaruhi oleh lokasi tempat tinggal.

\section{METODE PENELITIAN}

Metode penelitian ini dilakukan menggunakan jenis penelitian deskriptif kuantitatif. Pada penelitian ini mengetahui gambaran status demensia dan depresi pada lansia di wilayah kerja Puskesmas Guntur Kelurahan Sukamentri Garut. Populasi penelitian ini adalah lansia di tahun 2017 sebanyak 156 pasien yang tinggal di wilayah kerja Puskesmas Guntur Keluraha Sukamentri Garut sehingga jumlah lansia sebagai populasinya.

Pengambilan sampel menggunakan teknik simple random sampling dengan memilih responden yang sesuai dengan kriteria yaitu sebasar 112 responden. Teknik pengumpulan data dilakukan dengan menggunakan dua kuesioner menurut Teng dan Chui (1987) dan Joseph J. Ghallo (1998) untuk mengukur status demensi dan status depresi serta data dikelompokan ke dalam kategori baik dan kurang yang dianalisis menggunakan statistik deskriptif.

\section{HASIL PENELITIAN}

Penelitian ini bertujuan untuk mengetahui gambaran status demensia dan depresi pada lansia di Wilayah Kerja Puskesmas Guntur Kelurahan Sukamentri Garut. Pengumpulan data dilaksanakan pada bulan Juni sampai Juli 2018. Penelitian ini menggunakan metode deskriftif kuantitatif dengan teknik pengambilan sampling simple random sampling. Data dikumpulkan dengan cara menyebarkan kuesioner kepada 112 responden. Hasil penelitian disajikan dalam bentuk statistik deskritif dengan distribusi frekuensi. 
Tabel 1 Distribusi Frekuensi Karakteristik Demografi lansia di Wilayah Kerja Puskesmas Guntur Kelurahan Sukamentri Garut

\begin{tabular}{|c|c|c|}
\hline Data Demografi & Frekuensi (f) & Persentase (\%) \\
\hline \multicolumn{3}{|l|}{ Usia } \\
\hline 60-74 taahun (eldery) & 102 & 91.1 \\
\hline 75-90 tahun ( usia tua) & 10 & 8.9 \\
\hline \multicolumn{3}{|l|}{ Jenis Kelamin } \\
\hline Laki-laki & 53 & 47.3 \\
\hline Perempuan & 59 & 52.7 \\
\hline Suku Bangsa & 112 & 100.0 \\
\hline \multicolumn{3}{|l|}{ Sunda } \\
\hline \multicolumn{3}{|l|}{ Status Pernikahan } \\
\hline Menikah & 96 & 85.7 \\
\hline Janda/duda & 16 & 14.3 \\
\hline Pendidikan & 37 & \\
\hline Tidak Sekolah & 71 & 33.0 \\
\hline SD & 4 & 63.4 \\
\hline SLTP & & 3.6 \\
\hline \multicolumn{3}{|l|}{ Pekerjaan } \\
\hline Tidak Bekerja & 109 & 97.3 \\
\hline Pensiun & 3 & 2.7 \\
\hline \multicolumn{3}{|l|}{ Tinggal Dengan Siapa } \\
\hline Dengan Anak & 102 & 91.1 \\
\hline Dengan Pasangan & 10 & 8.9 \\
\hline
\end{tabular}

Berdasarkan tabel 1 hasil penelitian yang dilakukan di wilayah kerja puskesmas Guntur Kelurahan Sukamentri Garut, kepada 112 responden, diperoleh data karakteristik demografi yang menunjukan hampir seluruhnya responden dengan jumlah 102 lansia (91.1\%), jenis kelamin sebagian besar dengan jumlah 59 responden $(52.7 \%)$, suku bangsa seluruhnya sunda dengan jumlah 112 responden (100\%), status pernikahan hampir seluruhnya menikah dengan jumlah 96 responden $(85.7 \%)$, pendidikan terakhir sebagian besar berpendidikan SD dengan jumlah 71 responden $(63.4 \%)$, pekerjaan hampir seluruhnya tidak bekerja dengan jumlah 109 responden mellitus hampir seluruhnya tidak ada riwayat diabetes mellitus dengan jumlah 107 responden (95.5\%), riwayat kolesterol hampir seluruhnya tidak ada riwayat kolesterol dengan jumlah 95 responden ( $84.8 \%$ ), riwayat stroke hampir seluruhnya tidak ada riwayat stroke dengan jumlah 97 responden $(86.6 \%)$, riwayat olahraga hampir seluruhnya tidak ada riwayat olahraga dengan jumlah 97 responden (86.6\%), dan riwayat pikun hampir seluruhnya tidak ada riwayat pikun pada keluarganya dengan jumlah 100 responden (89.3\%).

Tabel 2 Distribusi Frekuensi Data Riwayat Kesehatan Responden di Wilayah Kerja Puskesmas Guntur Kelurahan Sukamentri kota Garut

\begin{tabular}{|l|l|l|}
\hline Data Riwayat Kesehatan & Frekuensi (f) & Presentase (\%) \\
\hline Riwayat Rokok & & \\
Tidak Pernah & 60 & 53.6 \\
Sudah Berhenti & 52 & 46.4 \\
\hline
\end{tabular}




\begin{tabular}{|l|l|l|}
\hline Riwayat Hipertensi & 31 & 27.7 \\
Ya & 81 & 72.3 \\
\hline Tidak & 5 & \\
Riwayat Diabetes Mellitus & 107 & 4.5 \\
Tidak & & 95.5 \\
\hline Riwayat Kolesterol & 17 & 15.2 \\
Ya & 95 & 84.8 \\
Tidak & & \\
\hline Riwayat Stroke & 15 & 13.4 \\
Ya & 97 & 86.6 \\
Tidak & & \\
\hline Riwayat Olahraga & 15 & 13.4 \\
Ya & 97 & 86.6 \\
Tidak & & \\
\hline Riwayat Pikun & 12 & 10.7 \\
Ya & 100 & 89.3 \\
Tidak & & \\
\hline
\end{tabular}

Berdasarkan table 2 hasil penelitian yang dilakukan di wilayah kerja puskesmas Guntur Kelurahan Sukamentri Garut, kepada 112 responden, diperoleh data karakteristik riwayat kesehatan yang menunjukan responden riwayat merokok sebagian besar tidak pernah meroko dengan jumlah 60 responden ( $53.6 \%$ ), riwayat hipertensi sebagian besar tidak pernah ada riwayat hipertensi dengan jumlah 81 responden (72.3\%), riwayat diabetes mellitus hampir seluruhnya tidak ada riwayat diabetes mellitus dengan jumlah 107 responden (95.5\%), riwayat kolesterol hampir seluruhnya tidak ada riwayat kolesterol dengan jumlah 95 responden ( 84.8\%), riwayat stroke dengan jumlah 97 responden (86.6\%), riwayat olahraga hampir seluruhnya tidak ada riwayat olahraga dengan jumlah 97 responden $(86.6 \%)$, dan riwayat pikun hampir seluruhnya tidak ada riwayat pikun pada keluarganya dengan jumlah 100 responden $(89.3 \%)$.

Tabel 3 Distribusi Responden Berdasarkan Status Demensia Pada Lansia di Wilayah Kerja Puskesma Guntur Kelurahan Sukamentri Garut

\begin{tabular}{|l|c|cc|}
\hline Data Demografi & Frekuensi (f) & Presentase (\%) & \\
\hline Demensia Berat & 15 & & 37.4 \\
\hline Demensia Ringan & 45 & & 49.1 \\
\hline Demensia Sedang/Normal & 55 & & \\
\hline Total & $\underline{112}$ & $\underline{100.0}$ &
\end{tabular}

Pada tabel 3 diatas didapatkan karakteristik responden berdasarkan status demensia, dengan demensia berat sebanyak $13,4 \%$ responden, sedangkan demensia sedang sebanyak $37,5 \%$ dan pada lansia yang demensia normal sebanyak $49,1 \%$.

Tabel 4 Distribusi Responden Berdasarkan Status Depresi Pada Lansia di Wilayah Kerja Puskesmas Guntur Kelurahan Sukamentri Garut

\begin{tabular}{|c|c|c|}
\hline Data Demografi & Frekuensi (f) & Presentase (\%) \\
\hline Normal & 32 & 2836 \\
\hline Depresi Ringan & 45 & 40.2 \\
\hline Depresi Sedang & 23 & 20.5 \\
\hline Depresi Berat & 12 & 10.7 \\
\hline Total & 112 & 100.0 \\
\hline
\end{tabular}




\section{PEMBAHASAN}

Berdasarkan hasil penelitian di atas, berikut akan diuraikan pembahasan mengenai gambaran status demensia dan depresi pada lansia di wilayah kerja puskesmas Guntur kelurahan Sukamentri Garut. Demensia adalah adalah sindrom terjadinya penurunan memori, berpikir, perilaku dan kemampuan melakukan aktivitas sehari-hari pada individu (WHO, 2016). Depresi adalah suatu gangguan mental umum yang ditandai dengan mood tertekan, kehilangan kesenangan atau minat, perasaan bersalah atau harga diri rendah, gangguan makan atau tidur, kurang energi, dan konsentrasi yang rendah. Masalah ini dapat akut atau kronik dan menyebabkan gangguan kemampuan individu untuk beraktivitas sehari-hari (WHO, 2010).

Hasil penelitian ini didapatkan demensia dalam kategori ringan, yaitu sebanyak 55 responden (49,1\%), dengan kategori demensia sedang sebanyak 45 responden (37,5\%), sedangkan kategori demensia berat sedang sebanyak 15 responden $(13,4 \%)$. Sedangkan hasil penelitian status depresi dalam kategori normal sebanyak 32 responden $(28,6 \%)$, kategori depresi ringan sebanyak 45 responden $(40.2 \%)$, kategori depresi sedang sebanyak 23 responden $(20,5$ $\%)$ dan kategori depresi berat sebanyak 12 responden $(10,7 \%)$. Temuan ini juga didukung oleh setiap domain demensia yang cenderung berada dalam kategori ringan, kecuali pada domain jenis kelamin.

Beberapa penelitian juga menunjukan bahwa hasil penelitian yang di kemukakan oleh Ningsih (2017) gambaran status demensia pada lansia di wilayah Kerja Puskesmas Ibrahin Adjie Kota Bandung, dengan metode penelitian deskriptif dengan pendekatan kuantitatif. Data di kumpulkan dengan menggunakan kuisioner Early Dementia

Questionnaire (EDQ), yang dilakukan pada 98 responden bahwa lansia yang termasuk kategori early dementia dengan persentasi $38,8 \%$ dan lansia yang termasuk kategori normal dengan persentasi $61,2 \%$. Dilihat dari 6 domain status demensia, daya ingat, konsentrasi, gejala, fisik, emosi, gangguan tidur dan gejala lain, yang dilakukan oleh peneliti didapatkan hasil domain konsentrasi yang cenderung tinggi sebanyak 70 responden $(71,4 \%)$ dan pada domain gejala lansia lain rendah sebanyak 83 responden (84,7\%). Berdasarkan karakteristik responden early dementia paling banyak pada usia 60-74 tahun sebanyak 26 responden $(39,4 \%)$, jenis kelamin perempuan sebanyak 29 responden $(40,9 \%)$ dan pada pendidikan sekolah dasar sebanyak 20 responden $(38,5 \%)$.

Demensia di wilayah kerja puskesmas Guntur kelurahan Sukamentri yang lebih rendah berdasarkan jenis kelamin yaitu perempuan 29 responden $(49.1 \%)$. Hal ini sejalan dengan penelitin yang dilakukan Sengkey (2017) bahwa kejadian Demensia lanjut usia di BPLU Senja Cerah provinsi Sulawesi Utara dengan presentase terbanyak gangguan kejadian demensia sedang, sementara penelitian yang dilakukan Ukus (2015) menyebutkan sebelum di berikan logoterapi mengenai kebermaknaan hidup terdapat 11 responden yang mengalami kebermaknaan hidup kurang dan 4 responden yang mengalami kebermaknaan hidu cukup. Sedangkan sesudah di berikan logoterapi mengenai kebermakaan hidup terdapat 12 responden yang mengalami kebermaknaan hidup cukup dan 3 responden yang mengalami kebermaknaan hidup kurang.

Hasil penelitian ini memiliki kesamaan dengan hasil penelitian yang dilakukan oleh Marta (2012), didapatkan tidak adanya hubungan yang signifikan antara dukungan keluarga dengan depresi pada lansia dengan nilai $p=0,661$. Hal ini disebabkan karena para lansia tidak ingin menyusahkan keluarga dan ingin mandiri 
selama hidup di panti tersebut. Berdasarkan hasil wawancara dan pengamatan pada saat penelitian, sebagian besar lansia yang berada di Panti Sosial sudah jarang dan bahkan ada yang tidak pernah dikunjungi oleh keluarga. Hal ini dapat mempersulit komunikasi antara keluarga dengan lansia, sehingga lansia akan merasa kesepian karena kurangnya perhatian dan dukungan yang diberikan oleh keluarga. Dampak dari kurangnya perhatian dan dukungan dari keluarga salah satunya adalah dapat mencetuskan kejadian depresi.

Pada penelitian Prabhaswari (2015) hasil penelitian ini, didapatkan $24,4 \%$ sampel mengalami depresi. Angka depresi pada lansia perempuan ditemukan lebih tinggi, terdapat kecenderungan peningkatan angka depresi seiring bertambahnya usia dan rendahnya tingkat pendidikan. Lansia yang berstatus tidak menikah atau tidak bekerja juga menunjukkan angka depresi yang lebih tinggi dibandingkan kelompok lainnya. Simpulan penelitian ini adalah prevalensi depresi pada lansia di wilayah kerja Puskesmas Petang secara umum tergolong rendah, terutama pada lansia yang berusia lebih muda, berjenis kelamin laki-laki, berpendidikan tinggi, memiliki pasangan, dan masih bekerja. Penelitian yang

dilakukan Indriana et.al pada tahun 2010 pada 32 lansia Panti werdha Pucang Gading Semarang menunjukkan 81,25\% lansia mengalami stres berat dengan skor di atas 150 dan $18,75 \%$ menunjukkan keluhan sedang. Salah satu factor yang menyebabkan stres pada lansia di panti adalah ketiadaan kebersamaan dengan anggota keluarga sehingga mereka merasa dicampakan atau tersisih. Tetapi penelitian di daerah Jawa Tengah yang dilakukan oleh Syahnur R pada tahun 2006 tentang perbandingan stres antara lansia yang tinggal terpisah dari keluarga dengan lansia yang tinggal bersama keluarga menyatakan bahwa stres pada lansia tidak dipengaruhi oleh lokasi tempat tinggal.

\section{Status Demensia dan Depresi Berdasarkan Karakteristik Demografi Responden}

Hasil penelitian pada tabel 4.5 dan 4.6 menunjukan bahwa responden yang termasuk kategori demensi pada usia 60 tahun sampai 74 tahun yaitu, kategori demensia berat sebanyak 14 responden $(13,7 \%)$, kategori demensia sedang sebanyak 35 responden $(34,3 \%)$ dan kategori ringan sebanyak 53 responden $(52,0 \%)$. Sedangkan responden yang berusia 75 tahun sampai 90 tahun yaitu, kategori demensia berat 1 responden $(10,0 \%)$, kategori demensia sedang 7 responden $(70,0 \%)$ dan kategori demensia ringan 2 responden $(20,0 \%)$. Penelitian yang dilakukan oleh maryam, dkk (2015) menyebutkan bahwa lansia yang berusia > 65 tahun berpeluang untuk terjadi demensia.

Pada hasil penelitian demensia kategori berat sebanyak 9 responden $(35,6 \%)$ jenis kelamin perempuan, kategori demensia sedang sebanyak 35 responden $(34,3 \%)$ berjenis kelamin perempuan, kategori demensia ringan 53 responden $(52,0 \%)$ berjenis kelamin perempuan sedangkan demensia kategori berat sebanyak 6 responden $(11,3 \%)$ jenis kelamin laki, kategori demensia sedang sebanyak 21 responden $(39,6 \%)$ berjenis kelamin lakilaki, kategori demensia ringan 26 responden $(49,1 \%)$ berjenis kelamin lakilaki, dilihat dari hal tersebut hasil dari penelitian kategori usia 60 sampai 74 lebih banyak mendominasi sama halnya denga jenis kelamin , jenis kelamin perempuan lebih mendominasi dibandingkan dengan jenis kelami laki-laki. Azat et al (2013). Melakukan penelitian membedakan dari faktor terjadinya demensia antara dua jenis kelamin, Didapatkan hasil bahwa kejadian demensia lebih banyak terjadi pada perempuan, hal ini terjadi karena tingkat hipertensi, dan obesitas pada perempuan lebih tinggi daripada laki-laki. 
Hasil penelitian pada tabel 4.5 dan 4.6 menunjukan bahwa responden yang termasuk kategori depresi pada usia 60 tahun sampai 74 tahun yaitu, kategori Normal sebanyak 31 responden $(30,4 \%)$, kategori depresi ringan sedang sebanyak 41 responden $(40,2 \%)$ dan kategori depresi sedang sebanyak 20 responden $(9,6 \%)$, dan kategori depresi berat sebanyak 10 responden $(9,8 \%)$. Sedangkan responden yang berusia 75 tahun sampai 90 tahun yaitu, kategori Normal sebanyak 1 responden $(10,0 \%)$, kategori depresi ringan sedang sebanyak 4 responden $(40,0 \%)$ dan kategori depresi sedang sebanyak 3 responden $(30,0 \%)$, dan kategori depresi berat sebanyak 2 responden (20,2\%). Penelitian yang dilakukan oleh (penelitian Prabhaswari, 2015) Berdasarkan hasil penelitian didapatkan bahwa responden yang mengalami depresi sebanyak 22 orang $(24,4 \%)$, sedangkan yang tidak

mengalami depresi lebih dari tiga kali lipatnya yakni sebanyak 68 orang $(75,6 \%)$. Proporsi kejadian depresi paling tinggi ditemukan pada kelompok usia 70 tahun ke atas. Ditinjau dari jenis kelamin, angka depresi lebih tinggi pada responden perempuan dibandingkan laki-laki. Proporsi depresi juga ditemukan lebih tinggi pada responden yang berpendidikan rendah $(27,6 \%)$, sedangkan di antara responden yang berpendidikan tinggi hanya satu orang $(11,1 \%)$ yang mengalami depresi. Responden yang berstatus tidak menikah memiliki proporsi depresi lebih tinggi. Begitu pula dengan responden yang tidak bekerja, memiliki angka depresi yang lebih tinggi dibandingkan dengan mereka yang masih bekerja.

Pada hasil penelitian depresi kategori normal sebanyak 18 responden $(30,5 \%)$ jenis kelamin perempuan, kategori depresi ringan sebanyak 22 responden $(37,3 \%)$ berjenis kelamin perempuan, kategori depresi sedang 12 responden $(20,3 \%)$ berjenis kelaminperempuan sedangkan demensia kategori berat sebanyak 7 responden $(11,9 \%)$ jenis kelamin perempuan, kategori depresi berat 14 responden $(26,4)$ berjenis kelamin perempuan. Kategori demensia sedang sebanyak 23 responden $(43,4 \%)$ berjenis kelamin laki-laki, kategori demensia ringan 11 responden $(20,8 \%)$ berjenis kelamin laki-laki, kategori depresi berat sebanyak 5 responden $(9,4)$ berjenis kelamin laki-laki, dilihat dari hal tersebut hasil dari penelitian kategori usia 60 sampai 74 lebih banyak mendominasi sama halnya denga jenis kelamin , jenis kelamin perempuan lebih mendominasi dibandingkan dengan jenis kelami laki-laki.

\section{Keterbatasan Penelitian}

Keterbatasan pada penelitian ini yaitu peneliti kesulitan jika responden tidak ingin ditemui atau tidak bersedia di ajak kerjasama dalam penelitiannya, peneliti melakukan door to door pada setiap lansia dan pembagian kuesionernya dengan cara observasi karena sebagian responden tidak mengerti.

\section{SIMPULAN}

Berdasarkan hasil penelitian yang dilakukan, dapat ditarik kesimpulan bahwa sebagian besar responden memiliki demensia dalam kategori ringan dan juga lansia yang depresi dalam kategori ringan, yang akan berdampak menggagu pola kehidupan aktivitas sehari-harinya, yang cenderung akan menigkat jika terus dibiarkan dan dianggap hal biasa oleh masyarakat. Depresi dianggap berpengaruh dalam timbulnya demensia, namun ada juga penelitian yang mengganggap demensia dapat timbul karena depresi dan muncul hanya sesaat yang sering disebut sebagai sindroma demensia dari depresi atau demensia.

\section{SARAN}

\section{Bagi Puskesmas}

Dari hasil penelitian ini disarankan menjadi data dasar dan sebagai bahan pertimbangan bagi pihak puskesmas dalam 
menentukan kebijakan terkait dengan upaya pelayanan kesehatan terhadap lanjut usia. Upaya yang dapat dilakukan dengan mengembangkan penyuluhan berupa informasi dan edukasi terkait demensia dan depresi kepada masyarakat, mengembangkan program kegiatan lansia yang dapat membina lansia dalam menjaga fungsi kognitif dan psikologi misalnya, dengan olahraga, membaca buku, dan melakukan kegiatan keterampilan.

\section{Bagi Institusi}

Penelitian ini diharapkan dapat dijadikan sebagai sumber bacaan tambahan untuk dosen maupun mahasiswa yang berhubungan dengan masalah gambaran status demensia dan depresi pada lansia.

\section{Bagi Keperawatan}

Setelah mendapatkan masukan dari hasil penelitian ini diharapkan bagi perawat khususnya perawat komunitas untuk dapat menjaga dan meningkatkan kualitas, peran dan fungsinya di masyarakat terhadap lansia untuk memberikan asuhan keperawatan baik fisik, mental ataupun spiritual.

\section{Bagi PenelitiSelanjutnya}

Hasil penelitian ini diharapkan sebagai sumber data untuk melakukan penelitian selanjutnya berupa faktor-faktor yang berhubungan dengan demensia dan depresi pada lansia di masyarakat dan dukungan keluarga terhadap lansia yang mengalami demensia dan depresi.

\section{DAFTAR PUSTAKA}

Arabi, Z., Aziz, N. A.zali, R., \& Puteh, S. E. (2013). Early Dementia Questionnaire (EDQ): A new sreening instrument for early dementia in primary care peactice. BMC family Practice http://www.biomedcentral.com/ 14712296/14/49.

Anderson, E.T., \& McFarlane, J. M. 36
(2011). Community as Partner: Theory and Practice in Nursing. Philadelphia: Wolters Kluwer Health/ Lippincott Williams \& Wilkins.

Anderson. M.A. (2007). Caring for Adults Holistically. Philadelphia: F.A. Davis Company

Arikunto,S. (2014). Prosedur Penelitian. Jakarta: Rineka Cipta.

Azad, N, A., Bugami, M. A., \& Loy, I. (2007). Gender Differences in Dementia Risk Factors. Gender Medicine/ Vol. 4, No 2, 120-126. https://www.ncbi.nlm.nih.gov/pu bmed/17707846.

Azizah,L. M. (2012). Keperawatan Lanjut Usia. Yogyakarta: Graha Ilmu.Badan Pusat Statistik. (2014). Angka Harapan Hidup Penduduk Beberapa Negara Jakarta. https://www.bps.go.id/linkTabel Statis/view/id/1517.

Badan Pusat Statistik. (2015). Statistik Penduduk Lanjut Usia 2014. https://www.bps.go.id/index.php/publi kasi/1117.

Badan penelitian dan pengembengan kesehatan kementerian

kesehatan RI. Riset kesehatan dasar tahun 2013. Available at: htt//www.litbang.depkes. go.id/sites/download/rkd2013/ Laporan_Riskesdas2013.PDF. Accessed May 25, 2017.

Hartati, S., \& Widayanti, C. G. (2010). Clock drawing: Asesmen untuk demensia (Studi deskriptif pada orang lanjut usia di kota Semarang). Jurnal Psikologi, 7(1), $1-10$.

Hernawati, I. (2006). Pedoman Tatalaksana Gizi Usian Lanjut Untuk Tenaga Kesehatan. Jakarta: Depkes. https://journal.unair.ac.id/down loadfull/IJCHN697909e05d40e3fullabstract.pdf.

Holmes, C., \& Amin, J, (2016). Dementia. Psychiatric Disorder. 687-690. https://www.sciencedirect.com/ 
science/article/pii/S135730391 6301670.

Kemenkes RI. (2012) Petunjuk Teknis Pos Pembinaan Terpadu Penyakit Tidak Menular (Posbindu PTM). Jakarta. https://pptm.depkes.go.id/cms/ frontend/ebook/JUKNIS REVISI. pdf.

Kemenkes RI. Buletin Jendela Data dan Informasi Kesehatan RI: Gambaran Kesehatan Lanjut Usia di Indonesia. Semester 1, 2013;hal:132.

Komnas Lansia. (2010). Pedoman Pelaksanaan Posbindu Lansia. Jakarta.

Leuckenotte, A. (2006). Gerontologic Nursing. Mosby: St. Louis.

Lopes, M. A., Xavier, A. J,. \& D’Orsi, E. (2016). Cognitive and functional Geriatrics, pp. 134- 139. https://www.sciencedirect.com/ science/journal/01674943/66.

Marchira, C. R., \& Wirasto, R. T. (2007). Pengaruh faktor-faktor psikososial dan insomnia terhadap depresi pada lansia di Kota Yogyakarta. Berita Kedokteran Masyarakat, 23(1).

Maryam, R. S., Ekasari, M. F,. Rosidawati, Jubaedi, A., \& Batubara, I. (2008). Mengenal Usia Lanjut dan Perawatannya. Jakarta. Salemba Medika.

Maryam, R. S,. Hartini, T,. \& Sumijatun. (2015). Hubungan Tingkat Pendidikan dan Aktivity Daily Living Dengan Dementia pada lanjut usia di Panti Werdha. Jakarta. https://ejournal.litbang.depkes.go.id/ index.php/kespro/article/view/4757.

Meiner, S. E. (Mosby Elsevier). Gerontologic Nursing. (5rd Edition). St Louis, Missouri: Mosby Elsevier.

Miller, C.A. (2012). Nursing Care of Older Adult: Theory and Practice.Philadelphia: Lippincott Williams \& Wilkins.

Mubarak, W. I,. \& Chayatin, N. (2009). Ilmu Keperwatan Komunitas.
Jakarta: salemba Medika.

Mujahidullah, K. (2012). Keperawatan Geriartik Merawat Lansia Dengan Cinta dan Kasih Sayang. Yogyakarta: Pustaka Pelajar.

Notoatmodjo, S. (2011). Kesehatan Masyarakat, Jakarta: Rineka Cipta.

Notoatmodjo, S. (2012). Metodologi Penelitian Kesehatan. Jakarta: PT Rineka Cipta.

Nugroho, W. (2008) Keperawatan Gerontik dan Geriatrik. Jakarta:EGC.

Nursalam. (2013). Metodologi Penelitian Ilmu Kepeawatan : Pendekatan Praktis. Jakarta: Salemba Medika.

Prabhaswari, L., \& Ariastuti, N. L. P. (2015). Gambaran Kejadian Depresi Pada Lanjut Usia Di Wilayah Kerja Puskesmas Petang I Kabupaten Badung Bali 2015. ISM. Bali, 7(1), 1-6.

Pratiwi, C. U,. Marliyati, S. A., \& Latifah,

M. (2013). Pola Konsumsi Pangan, Aktivitas Fisik, Riwayat Demensia Keluarga, dan Kejadian Demensia Pada Lansia di Panti Werdha Tresna Bogor. Jurnal Gizi dan Pangan,129-136.

Journal.ipb.ac.id > Home > Vol 8, No 2.

Sahathevan, R. (2015). Dementia: An Overview of Risk Factors. Kuala Lumpur: Universiti Kebangsaan Malaysia Medical Centre (UKMMC).

https://books.google.co.id/book $\underline{\text { s. }}$.

Salinas, R. M., Hiriart, M., Acosta, I., Sosa, A. L.,\& Prince, M. J. (2016). Type 2 diabetes mllitus as a Factorfor dementia in a Mexican population. Journal Diabetes and Its Complications.

Stanhope, M. (2006). Fondations pf Nursing In The Community.

Stuart, G.W. (2009). Principles and Practice of Psychiatric Nursing. St. Louis: Mosby.

Untari, I. (2014). Kajian Tingkat Demensia di PantiWerdha 
Darma Bakti Surakarta.

https://download.portalgaruda. org/article.php?article $=267269 \&$

val $=6682 \&$ title $=$ STUDY $\% 200 F \% 20$

THE\%ELDERLY\%20DEMENTIA\% 2

OIN\%2OPANTI\%WERDHA\%20\%20

DARMA\%BAKTI\%20SURAKARTA.

Wang, K. Y. (2012). The careburderof families with members having intelectual and developmental disorder: a review of the recent

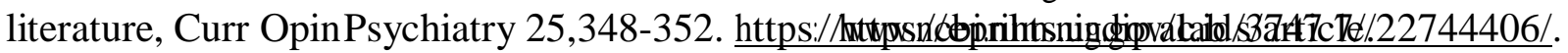

WHO. (2016).

Dementia.

https://www.who.int/mediacentr e/factssheet/fs362/en/.

Widyastuti, R. H. (2011). Gambaran Beban Keluarga dalam Merawat Lansia Dengan Demensia di Kelurahan Pancoran Mas, Depo, Jawa Barat:Studi

Fenomenologi, Purwokerto: 